\title{
Twin Pillars Policy: Engagement of US-Iran Foreign Affairs during the Last Two Decades of Pahlavi Dynasty
}

\author{
Majid Behestani ${ }^{1}$ \& Mehdi Hedayati Shahidani ${ }^{2}$ \\ ${ }^{1}$ International Relations at the University of Tehran, Iran \\ ${ }^{2}$ International Relations at Kazan Federal University, Russia \\ Correspondence: Mehdi Hedayati Shahidani, Institute International Relations, History \& Oriental Studies, Kazan \\ Federal University, 420111, Kazan, Russia. Tel: 79-2-7423-5507. E-mail: Mehdi.hedayati88@gmail.com
}

Received: May 21, 2014 Accepted: September 24, 2014 Online Published: December 20, 2014

doi:10.5539/ass.v11n2p20

URL: http://dx.doi.org/10.5539/ass.v11n2p20

\begin{abstract}
During second Pahlavi period, not only political-diplomatic relations between Iran and the U.S. were broken off, but at the same time, an excessive growth in bilateral relations can also be observed. Alongside the détente, U.S.'s military withdrawal from Vietnam, and the outbreak of protests and civil movements in the U.S., Iran had been entitled as the "gendarme of the region" and Shah became the defender of Western interests in the region. Such good relations are pursued under both Democrats and Republicans. The present article claims that becoming the gendarme of the region was not just a product of developments at the international level, but internal conditions were also influential. However, it is the U.S. decision which eventually gave precedence to the influence made by the international level. The reason that Iran was chosen, was based on its various political and leading capabilities in contrast to other countries of the region.
\end{abstract}

Keywords: foreign policy of Pahlavi regime, international relations, twin pollars policy, the policy of vietnamization, global peace structure, proxy war

\section{Introduction}

Although Iran-U.S relations were friendly and improving since the first period of Pahlavi dynasty, its significant progress in the last two decades of Pahlavi life is noteworthy. High level of imports and exports, establishment and growth of various American financial and investment companies in the country, presence of almost twenty thousand American military councilors, and above all, giving the title of "gendarme of the region" to Iran was herald of a change in equations. In fact this change was not only limited to Iran's internal developments, but it seemed that the conditions were changing for U.S. in all over the world. Hence the reason behind these transformations must be sought outside of Iran.

The main question which is being addressed in this article is hidden in this very issue. Which of the two factors of "U.S. imposition" or "Shah's decision" had priority in Iran's new regional role? As an answer, we are facing with two points of view: the first one is about an approach that put an emphasis on the permeability of assertive external forces and the other one is about giving precedence to internal options and decisions.

Works by the latter group do not consider internal forces and elements as being ineffective and recognize some degrees of independence for them. This is while the former group has identified power relations between the two governments which is defined as ruler/protector and submissive/protégé (Gasiorowski, p. 13), the first group emphasizes on the ruled government's relative independence (Ziba kalam, p. 16). However, at the end Gasiorowski says that the power relations were mutual and sometimes the submissive side was superior to the other side (Gasiorowski, pp. 176-177), but some try to depict more freedom of action for Reza Shah on the international scene (Ziba Kalam, p. 20).

Having a brief look at the events and relationship that existed between Iran and the U.S. after the 1953 Iranian coup d'état as well as the events of 1960s and 1970s, this article will explain how the patterns of modern American approach for global "peace structure" and "proxy war" is formed within the framework of former American foreign policy doctrine, based on modern post-Vietnam era, which was embodied in the Middle East as the twin pillars policy plan. Its final analysis says that within the same framework of Shah's passive foreign policy in front of great powers' decisions, accepting the title of "gendarme of the region" was not a resentful 
imposition but Shah's desirable option in order to enter a new era in his rule.

\section{Pahlavi Foreign Policy and America}

From the early days of his rule, Mohammad Reza Pahlavi (1941-1979) had positive view towards U.S.A which was getting better and stronger on a yearly basis. For Mohammad Reza Shah, U.S. coup against Mohammad Mosadegh, then-Iranian legal president, was a focal point in the relationship of the two states. It is the time that Shah's feelings towards Americans were comprised of a mixed of love and fear; those who had taken him to power had the able to dethrone him easily.

However, little by little, the two states got closer to each other. They got the ability to provide each other with their different regional and transregional interests. Shah allocated the U.S. an equal share of Iran's oil with that of England (40 percent), forcing the latter out of its permanent place as the ultimate power that ruled indisputably over Iran's oil.

The 1955 military-economic treaty of CENTO under U.S. supervision and the 1959 complementary mutual defense agreement between both countries indicates U.S.'s gradual permeation into Iran. Establishment of Iranian ministry of Intelligence (SAVAK), in addition to chief participation in establishing and investment in Iran's financial and commercial market, alongside the cultural issues are among other activities of US in Iran during 1950s onward.

The last two decades of Shah was the climax of these events. This period can be called the period of complete engagement of Shah's policies with U.S. interests and commands both in internal and external scales. Beginning from the first years of 1960s under the new Iranian foreign policy of "national independence", this period, unlike its confusing name, increased the process of Shah's one-sided dependence and allegiance to the American government.

\subsection{The Illusion of "Great Civilization"}

Having fixed his political power by suppressing the discontented leftist, nationalist, and religious forces, finding obedient individuals and through the establishment of the horrific SAVAK agency, Shah, who had a staggering oil income, was now willing to satisfy his regional hegemonic desires. The most key activities that Mohammad Reza Pahlavi did to prepare the ground for the fulfillment of this desires includes the attempts to satisfy the great powers by building ties with the conservative states in the region as well as Israel in order to satisfy the U.S., obtaining weapons for civil suppression and exterritorial attacks, injecting money supply into the society in order to satisfy the people, and suppression of the people's discontent. In 1962, Shah launched the "Land Reform" program once again. From 1940 until 1970 there was a period which was parallel with the era of independence movements in the third world countries; a fever for "modernization" caught the world. Shah thought that the country had all the necessary conditions to become a world power and in case of negligence in this regard, his reputation would be damaged. Americans were eager about the socio-economic reforms to be undertaken and it had two reasons: First, analysts in the White House thought that a backward and underdeveloped nation would provide a good ground for the propagation of and attraction to Communism (Presidential Research etc., pp. 6-25). Such a danger was felt much more intensely thanks to Iran's adjacency to the communist Soviet Union and excessive activities by the Tudeh party in Iran. Secondly, western economy was in needed of new markets. Iranian traditional society doesn't accept modernization and American life style. Shah had intended to provide Iranians with new circumstances in a short time.

\subsection{US, Ali Amini and White Revolution Show}

Mohammad Reza Shah, by taking the pose of a reformist, powerful, and propitious ruler, presented his "White Revolution", which he called "The Revolution of Shah and the Nation" in January 1963. Shah's weakness and Iran's adjacency to Soviet Union made the U.S. increase its support for Shah. Indeed such a support was not for free. In return, the U.S. was intended to possess the energy and raw material resources. It also wanted to keep not only a regional partner for itself but a rich customer who spends a great deal of money on military as well as other fields. More importantly, U.S. wanted to penetrate the region, establish permanent military bases, and defend its own interests in the region from the communist neighbor's encroachments (Cottom, pp. 56-57).

Shah and U.S. mutual regional interests against Communism and fundamentalism led to sign a mutual military treaty with each other (Avery, Hambly, \& Melville, p. 437). Apart from Soviet's threats against Iran, this treaty took place in a situation in which the Arabs were fighting Israel and Arab world was filled with revolutionary and Naserist feelings. Also the Muslim Brotherhood movement in Arab nations against the rulers put much pressure on the West and all of these conditions resulted in West-backed Arabs such as Saudi Arabia dare not to support Iran (seen as a West's partner). Afghanistan and India also were not optimistic towards this behavior of 
the Shah, especially since Pakistan as Iran's ally in CENTO Treaty was at war against India.

In exchange for such amount of pressure, Shah expected that U.S. would support his reign within and beyond (Avery, Hambly, \& Melville, p. 196). Gasiorowski called the relationship during 1960s and 1970s as cliency. "Cliency Relationship among countries is one for the benefit of both sides and attentive to the security between the states of both countries, which have great difference in terms of vastness, richness, and strength" (Gaziorsky, p. 12). Within these years along with satisfying Shah's regional greed and ambitions by sending advanced equipment, goods and services, and by putting a lid on Shah's despotic crimes in the country U.S. supported him from the danger of Communism and they tried to solve Shah's regional relations by removing the misunderstandings. Apart from Shah's massive arm purchases from the West particularly from the U.S., the climax of this buying and selling is dated in the time of Nixon's presidency who in a specific address to the ministry of defense, excludes Iran's requests for purchasing conventional arms free from approval (amoozgar, 1996, p. 501). According to this ruling only nuclear weapons were the exceptions.

The warmth of relations between Shah and the U.S. dates back especially to the time of Nixon's presidency. Entangled in Vietnam's scandal, he paid little attention to Shah's behavior and deeds, accepting them all. In a letter to American ambassador in Iran he wrote in 1968 that "My relationship with his highness is the real happiness of my presidency." (Mahdavi, 2001, p. 343) James Bill, the famous professor and the head of International Studies of "William and Mary" University reveals the earnest and vast relations of Pahlavis and Rockefellers and links the secret behind earnestness and influence of Kissinger in Iran's court to his relationship with the Rockefellers (Bill, 1992, p. 428). This was to the extent that Kissinger in his visit to Tehran calls the relations between Iran and the U.S. beyond official friendly relations but rather family-oriented ones.

In the beginning of 1969, Shah called Iran and U.S. as "natural allies". Within these years the relations were becoming deeper and more stable and American experts and councilors had literally taken over all areas of Iran's politics, economics, education, industry, and mass communication. During Johnson's time in a 200 million and a 600 million dollar deals and also during Nixon Shah spent a sum of 14.4 million dollars for his purchases from the U.S. (Mahdavi, p. 462).

In the book "White Revolution", having mentioned the necessity for accepting and acting in accordance with significant developments which was happening in human society all over the world and the fact that this issue had resulted in some tensions and crises in the societies, Shah proposed "Independent National Policy" which suggested two solutions for eliminating the crisis and establishing stability. This was planned by establishing social justice inside and social and economic justice in the global system (Pahlavi, p. 190). Shah's speech in the first session of fifth development program in Persepolis on 6th November 1972 reveals his ambitions. He called Iran's front line beyond the Persian Gulf and including the Indian Ocean, saying: “... That's why our responsibility has been completely altered and we should pay attention to some parts of the country which we formerly did not even think about and we are now facing fronts which had not existed in the past." All of Shah's actions showed that he knew himself as the regional power and was enjoying the role of being "region's gendarme".

\section{American Foreign Policy: Transitional Period}

United States under the influence of Wilsoninsm tended to have direct, or at least influential, and significant presence in all critical points of the globe. It had the intention to disseminate all over the world the absolute, superior and universal American values such as democracy, freedom, and human rights. As a result, during the first three decades after the War, U.S. entered into two big Asian wars along with some small interference in internal affairs of other states in the world from Latin America to Eastern Asia. In this period, under the framework of "Containment Policy", U.S. was in the front line of all international crises. Proposed by George Kennan (1947), this policy determined the behavior of the then-U.S. presidents from Kennedy to Johnson.

This approach required U.S. to employ a power two time greater than before that put a burden on the shoulders of American tax-payers. On the other side, the crimes of American soldiers and the interventions, and conspiracies of their officials and the disclosure of these facts had internationally damaged U.S.'s humanitarian and human rights oriented actions that led to the weakening of their justifying power domestically. Hence, the belief in the rightfulness of U.S. had been changing into self-hatred and the policy of power expansion over the world got criticized (Kissinger, p. 422).

Vietnam War can be regarded as a turning point in the history of U.S. foreign policy and, as a result, in international politics. Rorty speaks negatively about the period of Vietnam War, because the pressure that this war along with some other wrong measures taken by the ruling power has inflicted a pressure on the society especially on the academic community that caused some sort of discouragement and dismay to spread in the 
society. As a result it led to the great "disappointment" of American left reformists. This broke the "American national pride". In his opinion, the new American identity was distant from what the fathers had defined, reproducing itself in the guise of armed soldiers busy with shedding blood and occupying faraway lands (Rorty, p. 69).

What had the most importance for the foreign policy-makers of the United States was to "maintain the U.S. position in the world". The events of three decades after the World War II, and internationalist foreign policy of U.S. Presidents caused U.S. total control over the world to be faced with doubt and, as a result, it needed to perform a total revision of its technique.

\subsection{Nixon's View of the New Situation}

For Americans, Vietnam War did not begin from 1965 because at the same time the French army was present there and provided the South Vietnam (the anti-communist side) with much armament, spiritual support and especially financial support. According to a 1965 report, the total amount of money that U.S. put into Vietnam front covered 80 percent of all costs (Jasbi, p. 27). Nonetheless, as the French army retreated and the proposal of the Domino Theory (Note 1) U.S. called itself the leader of the free world and in the front lines against the world of darkness, saw itself morally responsible to be present in Vietnam's hell. But not more than three years had passed when the White House noticed the heavy and nonreturnable costs of being in Vietnam.

Although Nixon had once declared that if they allow Chinese leaders win, they will increase their expansionism and then, Thailand, Indonesia, Malaysia, and even Japan will be in danger of falling into the trap of Communism, and in his opinion "China knew only the language of power (Torabi, pp. 172-180).

However social peace movements against war and against rulers' absolutism, along with global realities, made Nixon and his advisors run for the presidency with the idea of introducing fundamental changes in the foreign policy. One should pay attention to the support of democrat President (Lindon Johnson) and his republican vice-president (Richard Nixon) in taking a unique stance in case of Vietnam. Due to his liberalist views, Johnson gave priority to "American global values", taking any kind of negligence towards it as something for the benefit of devil's frontline and forces of darkness. But the republican Nixon was influenced by realists such as Kenan and Kissinger. For him "national interests" of the U.S. had the priority. He regarded the Western bloc in a confrontation against the Eastern bloc and Vietnam, a force in Communist eastern borderline. Thus abandoning the West's friend for South Vietnam against the Communism's front line was against the U.S. interests for him. Accordingly, once faced with the heavy costs of Vietnam War, he left Vietnam in the framework of reducing the tensions and bargaining with Eastern forces. After gaining people's trust, in Guam Island in July 22, 1969 in his first official speech, he explained the new positions and programs of the United States known as the "Nixon's Doctrine":

"First, the United States will keep all of its treaty commitments. Second, we shall provide a shield if a nuclear power threatens the freedom of a nation allied with us or that of a nation whose survival we consider vital to our security. Third, in cases involving other types of aggression, we shall provide military and economic assistance when requested in accordance with our treaty commitments. But we shall look to the nation directly threatened to assume the primary responsibility of providing the manpower for its defense (Nixon, a).

In terms of foreign policy the most important foreign policy issue of Nixon's government was the management of the new international system in accordance with important and dangerous developments. On one side, due to the war costs and the pressure of the opposition and internal pacifists, the army was forced to leave Asia and on the other hand, this was contrary to the leading of the free world, supporting allies and containing the Communist movement. The government's view was about a "noble abandonment" so that U.S.'s "credibility" and "honor" would be maintained. In this regard, the policy of "Vietnamization" emerged from the policy-making meetings in the White House.

Within the detent years Nixon implied that regions such as Asia, including Vietnam, are not places in which power of the U.S. would be weakened or harmed, but the local governments themselves should be made stronger, the very same thing which Nixon called "Asia for Asians".

Nevertheless, it was not meant that U.S. would suddenly leave the battle fields or its supports thrown behind these states would be stopped, but from 1968 to 1971 (the end of Vietnam's crisis) only the number of American soldiers was reduced and heavy weapons and rockets were avoided. Thus in another step a direct confrontation between the two superpowers was prevented.

Nevertheless, it was not meant that U.S. would suddenly leave the battle fields or its supports thrown behind these states would be stopped, but from 1968 to 1971 (the end of Vietnam's crisis) only the number of American 
soldiers was reduced and heavy weapons and rockets were avoided. Thus in another step a direct confrontation between the two superpowers was prevented. Despite its appearance which should have been in accordance to the tendencies of U.S. arm corporations and factories, Vietnam's erosive war had been opposed by them because in Vietnam War only simple weapons were used and this happened while these factories were after employing complicated and heavy weapons and military instruments such as different types of long-range weapons and rockets.

\subsection{Sociology of Nixon's Foreign Policy}

In his book, Kissinger explained the realist view of the President; that he did not like Wilson's absolute view of natural good or bad, that he did not take peace and stability as the main conditions but believed they should be obtained by vigilant attempts, that he did not regard human as essentially good and assumed the public security system as deficient. He called U.S.'s inevitable role of democracy building in the world as unreal and strange (Kissinger, p. 419).

Nixon, however, believed in Wilson's mottos and values but in an international framework and U.S.'s inevitable role of leading it, and regarded them as exaggerated and opposite to global realities and international politics. Thus while putting an attempt to keep the Wilson's beliefs held by its predecessors; he tried to found his foreign policy on the principles of the realist view, based on the U.S. national interests.

He was not facing simple situation. American society is loyal to its values and actually considers them to be universal. Thus he regarded any compromise and giving concessions to the East as opposite to its values and ideals. In this view, U.S. should at first place correct the East from inside and then it would be possible to negotiate with them about the global management (Kissinger, pp. 422-479).

But on the other hand, although the protests by pacifists and American tax-payers provided the ground for the forces to leave the Vietnam and all of East Asia, how did the new plan got accepted? It should be said that this plan is in harmony with the economic spirit of the Americans. Liberal economy of the United States has accepted to limit the government's role in mere monitoring and have macro-management approach on all human resources and national capacities. In return, it would assign entrepreneurship and micro-management aspects to local and private workforces. According to this logic, in the balance of cost and benefit the biggest profit will go to the government, the society, and the economy of the private sector. Hence, one can call two-pillar policy in the general plan of Vietnamizing as a kind of privatization of foreign policy and managing the war outside the borders.

After dividing U.S.'s post-World War II foreign policy in two parts of Truman security doctrine and Bush security doctrine, Roxana Sjostedt recalls the difference and common points of these two. Accordingly, the most important common point in these two doctrines is that in both there is a great universal danger against the U.S., West and the International System (Communism and currently Islamism) that its destruction is a burden on the shoulders of American people as the guards of the Western civilization and the keepers of international peace and security. She concludes that culture and anthropology of the U.S. shows that they are a people with a sense of responsibility for the world and have always had this excessive belief that they are responsible for the expansion of defined Western norms (Sjöstedt, pp. 249-250).

\subsection{Kissingerian Realism in Foreign Policy}

But Nixon's doctrine was general and needed to be organized. The greatest influence in strategic change from Wilsonism to realism was done by his foreign minister, Henry Kissinger. In an essential turn, he altered militaristic strategy of United States from "total war" to "limited war". Influenced by Robert Osgood's limited war plan, he founded his own theory in 1975 by writing the book "Nuclear Weapons and Foreign Policy". In the first place, he advises that there should be nuclear power and nuclear war plans so that when necessary they can be used to defend U.S. national interests. Yet on the other hand, the conventional power must also be enhanced: limited war is what he calls average use of power may result in much higher political efficiencies than holding onto an extensive total war. Such a limited war, also, gives us the best opportunities to apply strategic changes in accordance with our interests and desires (Torabi, p. 181).

In the new approach, he outweighed policy and diplomacy over military and his emphasis on nuclear weapon should be interpreted as a political tool. For him nuclear doubt and fear will result in deterrence, hence he knew well that there will not be any nuclear war. Detent years strengthened this approach. Signing the NPT and the treaty of SALT 1 and 2 in the years coming after the Cuban crisis was done to bring trust to and secure the situation of the two world superpowers.

The United States had gradually managed to settle the problems; exiting from Vietnam, reducing tensions among 
the three powers of China, Soviet and U.S., signing the Berlin Treaty, and the European Security Conference that took place consecutively. Such agreements are in such a way that somehow the later attempts by Soviet Union were neglected by the U.S. Every transboundary confrontation by the Soviet Union with its opposition used to be encountered with a quick and negative reaction from the United States, but Prague's bloody spring in 1969 was neglected so that the years of Detent and trust building would passed smoothly.

\subsection{Peace Structure, Vietnamization, and Proxy War}

Such issues in Nixon's time made Kissinger design the political plan of "Vital Regions" within the framework of "Peace structure" for the U.S. national interests. It was true that U.S. did not have the former ability for confrontation but it also was afraid of communism to gain the world. The most vulnerable points were located in the borderlines of China and Soviet thus, excluding U.S. geographical territory and that of its Western European allies, if other points were not in the U.S. first security ring but were regarded as "vital regions".

Accordingly, U.S. looked at Iran, Turkey, Afghanistan, and other countries of Eastern bloc (vital regions) as "hygienic belt" that kept other parts of the world safe from communist microbes.

What was intended from "peace structure" was that international system has a single totality which is composed of several vital regions. Due to the responsibility, commitments, and national interests of the United States on one hand, and the high possibility for the conflict of interests in these regions, on the other, it is necessary that a single security-political structure covers them all; a structure which will keep the "international peace and security" in the new world under the U.S. leadership. Kissinger compared this structure to a building that needed sturdy pillars in sensitive points in order to stand. The survival of the building was dependent on the survival of its pillars.

While England was forced to leave the formerly-colonized Eastern regions, it was not logical that U.S. leave the Eastern front too. Because this would have resulted in disorganization of region's security arrangement and would change the balance to the detriment of the Western bloc. Therefore, the next plan of U.S. foreign policy should not violate the general commitments of the White House. Additionally, until two decades before that, U.S. was regarded as the unique example of freedom, and the only one that bears the difficulties of keeping international peace and security and that of the global attempts for improving and developing world economy (Donan, p. 84).

Nixon's decision is that, though bitter, the world realities should be managed attentively. Hence while keeping the hygienic belt around the Eastern bloc; it was necessary that the control of each region be given to allies and forces loyal to the West, that is to say, to put the evil forces of Asia against the good forces of that region. Vietnamization means to give more responsibility to regional allies and to equip them for an indirect fight with the Eastern bloc.

Nixon claimed that it was revealed that Communism was not going to be the future face of Asia. Asia could both be a threat to a balance to the detriment of the West and a source for solving Asian problems with Asian responses through cooperative actions. While Miyakawa terms the new U.S. foreign policy as regionalism (Miyakawa, p. 5), which shows that, United States was not able to assume global commitments as a superpower but was the first among the equals. According to an author, the goal of Vietnamization was to stop another Vietnam from being repeated but the Asian power continues to exist (Donan, p. 82).

As a matter of fact, such a claim that "Communism is no more the future face of Asia" does not mean that the danger of Communism has been warded off. Following policies and actions of Nixon show that all of their anxiety was the spread of the virus called "Becoming Soviet". Apart from a political bluff to belittle the enemy this claim can be analyzed under the framework of justifying the new era's plan and its related new policy.

Nixon's new conference in Guam in 25th July, 1969 should be looked at as an important turning point in understanding the new U.S. foreign policy. Here he calls Asia as the most important source of threat for the world peace and emphasizes America's serious role in Asia. Nixon's report of world's situation has five sections: 1. Western Europe and Japan has passed behind the destructions of World War II.

2. New states had reached some degrees of development not in the terms of political and economic aspects but from the perspective of national pride and securing authority.

3. Eastern bloc has become fragile.

4. The balance has changed from the U.S military prominence to a strategic stasis with the Soviet Union.

5. The importance and strength of old ideologies like Marxism, Leninism, and Liberal Democracy for shaping the future behavior of states has been reduced. 
On the other hand he has much hope in world's advancement due to the capabilities, human resources, and raw material in Asia. This shows that Nixon's message to the domestic U.S. society was that even though people, pacifists, and oppositions who wanted to leave from Vietnam and other parts of the world, U.S. presence in Asia was inevitable in other way round.

Besides he pointed at two important new factors that were influential on foreign behavior of the U.S.:

1. an increasing sense of Nationalism in Asia;

2. Asians' discontent for being dictated from outside. The plan "Asia for Asians" means America has to emphasize its role in Asia but should not dictate (Nixon, a).

In order to prepare the management of the new situation, a structure and a new definition of concepts had to be presented. In the Nixon-Kissinger 1970 report, peace was defined as thus: "Peace means more than absence of war. It is the lasting structure of international relations which inhibit or eliminate the reasons of war." The new situation was the same "peace structure" that in order to put it into effect it was required to plan Vietnamization (Note 2) and proxy war. The new policy involved three parts:

1. Existence of "partner": not in the sense of a close collaboration with the allies, but being in the sense of friends and allies who are able to stand by themselves. Yet it should be noted that old partners would not be forsaken since the principle of "stability" is of key importance so that allies would not be disappointed of being able to lean on the U.S.;

2. Capability: often militarily and in an adequate degree to protect the vital interests. Nixon was dissatisfied with previous government's excessively strict militaristic approach, based on complete elimination of the enemy. He was inclined to the variety of military approaches with keeping the safety of American citizens which led to his government's interest in controlling weapons;

3. Penchant for negotiating with the enemies (Donan, pp. 85-86).

\subsection{Reasons for Vietnamization}

Anyway in the new period, the main trouble for U.S. foreign policy was in the Eastern Asia. Because of the far distance from the United States' borderlines, the ambiguity on the future of the war as Vietnam's frontline got more complicated and the heavy economic burden on the Americans, the continuation of presence or making new commitments was not acceptable for the people. The exit made by the American military forces from other parts of the world, while it was to some extend in order to seize the opportunity (using the available situations as a justifying background for the reduction of direct presence in all critical points), was done rather to reduce the potential and possible costs of maintenance and management of military bases in the crisis-ridden territories.

Some do not regard the planning of the Vietnamization policy as opposite or complete substitute for the containment policy. In this perspective the containment policy is the cornerstone of Nixon's approach:

1. Giving priority to Europe and protecting it against the threat of Communism;

2. Due to Europe's refusal from buying weapons from the U.S., with Nixon's emphasis, led to the finding of new weapons markets;

3. It could protect the lives of American soldiers (Jasper, pp. 35-37)." Generally one can count the differences of Nixon's approach from previous American governments' approaches as follows:

- Return to Kenan's defense theory (Containment Policy);

- Preference of decision making in National Security Council and marginalization of foreign ministry;

- Separation of good Communism (China) and the bad one (Soviet) and trying to break them apart;

- Preference of economic tools over military approach;

- Enhancing anti-communist forces instead of exclusive focus on military forces (two-pillar policy). U.S. assistance in Iran's modernization weakened Shah's position inside and gave inverse results. America's assistance in Iran's modernization weakened Shah's position inside and gave reverse results. Results of this policy are strategy consistency along with huge global successes and failures in the region (Worley, p. 9).

According to another writer, controlling the region without disembarking any troops there, permanent access to oil for industrial Western world and Japan plus containing the Soviet Union were among the regional goals of the U.S. Hence two-pillar policy was not a spontaneous phenomenon influenced by defeats in Vietnam but it "was a premeditated policy to arm the Shah of Iran as a U.S. surrogate, to bypass congressional oversight, and to prop up the sagging U.S. defense industry. The Doctrine was an attempt to balance the geo-political imperatives of 
Soviet containment and access to oil with the need to satisfy domestic pressures, and it was an astute political solution in the short term (Jasper, p. 131)". More precisely, paying attention to United States' demands and Shah's ambitions, he would achieve the role of "gendarme of the region" sooner or later.

\subsection{Kissingerian Realism Peeling Kenanian Realism}

The last point was rooted in the realist nature of the White House's first man. In realist view, elimination of the enemy is a sign of idealists, while diplomacy means bargaining and negotiation in order to keep the necessary national interests of the international system (Morgenthau, p. 563).

The separation of domestic issues and the foreign policy is a topic that has a realist identity in the new policy. While George Kenan is known as the most important foreign strategist in the White House before Kissinger's presence, his linking view between the domestic issues with a state's external issues was being followed. This was while both strategists have a realist origin (Dougherty \& Pfaltzgraff, p. 88), but Kissinger showed inclination to the realist separatist principle. Kenan said that the only way to prevent Soviet's expansionism is to make changes in its internal structure. Such a claim would usually be heard by the Liberalists. Nixon, while rejecting some of the Soviet's features, yet our behavior would be set in accordance with its foreign behavior (Donan, p. 88).

Kissinger's other criticism of the predominant foreign policy of U.S. Department of State is the Liberal international thought saying that United States' energy is reducing incorrectly and unnecessarily. He wanted a new approach in European classical way of governance in relation with American foreign behavior, i.e. neither U.S. isolation from the world nor U.S. domination over it but accepting the necessary role of stabilizing factor in keeping the balance of power without which neither justice nor peace is possible. In this approach the government should enhance its ruling tools for indirect global presence and ask other allies carry out their roles as much as they can. Therefore, Kissinger had an important historical role in erasing Liberalism from the thought that rules on the U.S. foreign behavior and enhancement of realist ideas, though as Reagan's government took power, return to Liberalism commenced. In addition to his peace structure he utilized "trilateral diplomacy" in the foreign ministry. Opening negotiations with communist wing (China and Soviet Union) as well as paling the ideological dimensions of the previous American generation with flexibility and high resilience are determinant of this policy (Hendrickson, p. 4). Within this policy, U.S. tried to make China more indifferent to its own dangers and make it more sensitized towards the serious and direct danger of the Soviet.

\section{Two Pillars Policy}

From the plans of "Peace Structure" and "Vietnamization" within American strategy, two pillars policy emerges. According to this plan two regional powers of Iran and Saudi Arabia act as two regional pillars of resistance and maintenance of Persian Gulf and Middle East's trench for the Western camp. Hence "outside Persian Gulf region, Iran became increasingly active in Africa and Arab's war against Israel". In this plan Iran's role is more distinguished than that of Saudi Arabia.

\subsection{Why Iran?}

It was mentioned that all of the conditions after the World War II due to the growth of Islamism and Arabic nationalism, the tendency among Arab nations and some of the revolutionary states of the Middle East was in theory more inclined towards the leftist thoughts but in practice it was more inclined to the foreign behavior of the Eastern bloc. Also during these years the newly-founded Arab countries were doubtful about their security after the exit of the English forces, thus accepted a west-backed regional power in order that it brings limited stability and maintain the region's security; gradually the relations became more intimate. In such a situation, U.S. needed to prevent Arab movements which were receiving military supports of the Soviet or to move against them and simultaneously direct Arab leaders more inclined to itself and take control of the Middle East's peace process (Kissinger, p. 468). Iran's participation in support for the West in Vietnam War, its conflicts with Iraq, supporting Pakistan against India, and more important of all, Zufar War was done in this regard. In order to approach the West and to show his good will as much as possible, Shah also built a huge fleet in Chabahar port which would secure the interests of the West and Iran in the Oman Sea, Persian Gulf, and the Indian Ocean (Torabi, p. 209).

Iran was a different and competent state in the region to gain the new role of the "gendarme". Iran had bad memories of Soviet adventurism after the World War II, and had an anti-communist feeling. It was regarded as a friend of Israel, controlled a large supply of oil that made it a rich country. Iran was in control of Hormoz Strait, and because of its large population was capable of building a big army and thus was provided with such a military power to manage its new role (Fuller, p. 249). Being located in the primary level of the hygienic belt and 
U.S. dependency on Shah as the stable pillar of the region conformed to the image Shah had of himself as a global strategist (Jasper, pp. 51-52).

Anti-American and anti-Israeli feelings among Middle Eastern Arab nations made Iran a good choice for Vietnamizing the region. Although Israel was hated among Iranians, and there was somehow a bad image of U.S. in their minds, in sum such an issue was rather weaker in Iran.

Oddly, American governments' view of Iran before the Revolution as a partner was always negative and disappointed. For example, from Eisenhower till Nixon, all U.S. presidents were skeptic about Shah's benefit for them and his capability in keeping the U.S. interests in the region. They also looked at Shah as unable to keep himself in power and as someone who relied on the external power (Mahdavi, p. 264).

Jasper says that in Americans' view from 1960s onward, the United States' potential enemies in the region were, ordered by their priority, Soviet, Iran, and Iraq, which amazingly such an idea has remained up to now (Jasper, p. 51). Simultaneously, having access to oil and protecting Israel were the two main concerns. Although the author does not explain clearly why Iran was regarded as a potential enemy for the U.S., he continued that for many reasons such as the overlap of the U.S. aspirations with Shah's ambitions such a role was given to Iran. Perhaps one can relate the history of Iranian empire, potential capability of being rich in terms of valuable raw material, being located in the biggest source of fossil fuels, Shah's ambitions for returning to the golden old days of a big empire, large population, and having political religion of Shiite Islam were all the reasons that made up the mostly negative and potentially adversary view of Iran among the heads of the White House. Yet Richard Cottom said that Washington was not in a situation to accept the risk of hurting a loyal state (Cottom, p. 130). Hence, while cutting the relationship with Shah's opposition, neglecting Mohammad Reza Shah's crimes and tyranny, in addition to accepting some of his desires (Gaziorosky, p. 176), Nixon encouraged him to buy more American weapons so as to better play the role of a "gendarme" and the keeper of the U.S. and West's vital interests in the region.

Yet a pillar itself should have a relative power and have the ability to bear the new military-security burden. Back then, most of the Middle Eastern states were renter and apart from having a low economic growth and GDP suffered from bureaucratic, financial, and political corruption. Among them, Iran had somewhat better off. But a bankrupt state or a developing one was not appropriate for this job. Therefore, the preparations of this job had to be made.

One year before the time when Nixon took power, the Congress passed a law setting conditions for weapon customers. According to Gun Control Act of 1968, there were three conditions for the buyers, including the one that the commerce should be made with a developed country but which is in need of those weapons and lack the infrastructure for their production and afford to pay for them in cash (Jasper, p. 43). This is while Iran was entitled as a developed country by the U.S. in 1967. This means that the country does not need U.S. loans and donations. Moreover, increase in oil price helped Iran and Saudi Arabia buy advanced weapons in mass and play the new role. As a result, Iran met all the required conditions of the aforementioned law (Jasper, p. 44).

Before this, something similar to the two pillar policy was adopted by the U.S. in Iran and the whole Middle East. For example, Eisenhower in his speech, which became famous as his doctrine, explicitly warned the Soviet Union from penetrating into this region, calling it as an attack on U.S. interests (Mahdavi, pp. 248-249). The treaty of CENTO had such a goal.

Consequently, Nixon-Kissinger strategy within the framework of permanent doctrine of U.S. national security paid more attention to the policy of arming the allies. Therefore arming the regional friends instead of direct military presence in sensitive points of the world was the most important determinant of the new strategy (Ziba Kalam, p. 156). It is natural that Nixon would write: "Although some regarded this doctrine as U.S. retreat from the undeveloped world, in fact it mentioned the only correct basis for permanent involvement of the U.S. in the issues related to the entire third world, especially in the Persian Gulf (Nixon,b, p. 264)". If we consider the meaning of "doctrine" as the regulations ruling the behavior, then we should take the general plan as well as the main regulations of a state's behavior as its doctrine. States, framing their internal and foreign policies actively, should not have doctrinal changes in the short term. On the contrary, difference in states will result in difference in strategies and tactics. It is expected that the doctrine alter while searching for a change in the legal-political structure or the state's decision to enter a new period. Hence, Nixon's new policy is analyzed as a strategy change at most. But in order to maintain direct quotation the phrase "Nixon's doctrine" was repeated. I agree with Amin Saikal's opinion that Shah had gradually managed to personally bring order to foreign policy which would both cover his dreams and conform to United States' interests (Avery et al., p. 196). 


\section{Conclusion}

After World War II United States left the Monroe Doctrine and based on Wilsonian values went for interference in all critical, in his own view, points which was also called "closed world". Taking part in two total and proxy wars in Asia which were very far from U.S. security and geographic area, along with participation and cooperation in many disputes along with small and big friction throughout the world such as many coups d'état, controlling civil unrests, presence in small battles in Africa and Latin America, and above all controlling the cold war with the Soviet Union, used up United States' energy and capability after three decades, putting former Wilsonian values into serious doubts.

Years of Detent, signing pacts and peace treaties, regional and international security regimes, arms control regimes, and the disarmament of the two superpowers along with Richard Nixon and his realist team who had come to power, set the stage ready for the U.S. to change its foreign policy strategy. Nixon who against all the surges of anti-war civil movements of 1960s, showed that he knows very well how to change his tune in different situations and set the foundations of U.S. new foreign policy upon "national interests" and not on the "national values". Consequently it is not odd that Moscow's crime in Prague in the spring of 1969 was considered as small and insignificant.

In the new strategy of the U.S., it would equip and support its regional allies in Asia so that they would support and protect themselves as well as Western interests and in case of a war and on the request of the invaded country, U.S. will send its forces. Accordingly, Kissinger, Nixon's Secretary of State, offered the "two-pillar policy" based on "gendarme" pattern for the Middle East. In this plan in addition to keeping an eye on maintaining the U.S. interests in the Middle East and the Persian Gulf, much attention had been paid to this security-based reality that has been created after the exit of England leaving a lack of stabilizing power in the east of Suez Canal.

The fact that the nation-states of the Persian Gulf region were newly born, especially and mostly the Middle Eastern nations, was indicative of the necessity of the presence of a stabilizing force. Since these states, due to their lack of popular political and social base and the existence of opposition movements were generally facing legitimacy crises. Among them Iran and Saudi Arabia, with more emphasis on Iran, because of their several geo-economic, geopolitical, and geostrategic reasons, in line with Shah's ambitious spirit, were able act as the region's "gendarme" in the absence of the U.S. and England. Cottom called Iran as the U.S. front most hygienic belt in the region.

Yet in the final analysis, within the international equations and internal conditions, we put the bigger emphasis on the first item. Since international conditions and the inability of the U.S. to continue the status quo, forced it to divide the international geographic environment, determine vital regions, and eventually feign its gendarme in the region. In the final step because of the appropriateness of Iran's conditions in all of its aspects for accepting such an important responsibility, this power was ascribed to this country. In other words, Iran's internal circumstances did not alter U.S. foreign policy, but --on the contrary-- if Iran was unprepared, U.S. would have sought another regional actor for this purpose.

Accordingly, while accepting one of the assumptions made by those who argue that Shah was not plainly a puppet then its generalization within the foreign policy would face a contradiction, especially during 1960s and 1970s. Iran's turning into a U.S. armory and as a main regional military base of the U.S., within the framework of the Cold War and the presence of thousands of American military in the country, even under the pompous title of "national independent policy", was nothing more than serving the U.S. as the gendarme of the region. Most of Shah's military campaigns were about to meet U.S. regional demands rather than serving Iran's interests. How can it be accepted that Shah in his foreign policy made decisions detached from the U.S. foreign policy, while he was threatened by the newly-established United Arab Emirates for the violation of territorial integrity and during these ups and downs was forced to give way to the independence of Bahrain province?

Even by ignoring Jasper in his claim that Iran and Iraq after the Soviet Union are considered as the U.S. potential enemies, still the quotation "Shah as an ally of the West" seems illogical. If it is said that some of Shah's minor behaviors were not accepted by the U.S. and England, it cannot be considered as a strong implication of Shah's foreign policy to be independent, even partially. It rather showed that Shah's being a "puppet" was not an imposed choice but it was Shah who accepted it wholeheartedly.

\section{References}

Amuzegar, J. (1991). The Dynamics of the Iranian Revolution: The Pahlavis' Triumph and Tragedy. New York, NY: Suny Press.

Avery, P., Hambly, G. R. G., \& Melville, C. P. (1991). The Cambridge History of Iran, Toм 7. Cambridge History. 
London.

Cottom, R. (1988). Iran and the United States: A Cold War Case Study. Pennsylvania, Pittsburgh, Pa: University of Pittsburgh Press.

Donan, J. E. (1974). The Nixon Doctrine and the Primacy of Détente. The Intercollegiate Review: A Journal of Scholarship and Opinion, 9(2), 77-97. Retrieved from http://www.mmisi.org/IR/09_02/dornan.pdf

Dougherty, J. E., \& Pfaltzgraff, R. L. (2000). Contending theories of international relations: A comprehensive survey (5th ed.). New York, NY: HarperCollins.

Fuller, E. G. (1991). The center of the universe: The geopolitics of Iran. Boulder, Colo.: Westview Press.

Gasiorowski, M. (1991). US Foreign Policy and the Shah: Building a Client State in Iran. Ithaca, NY: Cornell University Press.

Hendrickson, D. C. (1998). All the President's Acumen: The Paradox of Nixon's Foreign Policy. Review Essay, Foreign Affairs, 112-118. http://dx.doi.org/10.2307/20048881

James, A. B. (1988). The Eagle and the Lion: The Tragedy of American-Iranian Relations. Connecticut, New Haven, NH: Yale University Press.

Jasper, M. W. (1997). Security Assistance in Persian Gulf and the Roots of the Nixon Doctrine. A Thesis for M.A., Naval Postgraduate School, Monterey, California.

Kennan, G. (1947). The Sources of Soviet Conduct. Foreign Affairs, 26(2), 566-582.

Kissinger, H. (1994). Diplomacy. New York, NY: Simon \& Schuster.

Mahdavi, H. (2010). Iran's Foreign Policy during Pahlavi Era. Tehran, Published by Peykan.

Miyakawa, Y. (1985). U.S Foreign Policy and Asia in the 1970s: From the Nixon Doctrine to the Carter Doctrine, Nanzan University, 2, 9-26. Retrieved From http://www.ic.nanzan-u.ac.jp/AMERICA/kanko/ documents/02-2_Miyakawa.pdf

Morgenthau, H. J. (2005). Politics among Nations (7th ed.). New York, NY: McGraw-Hill.

Nixon, R. (1969). Informal Remarks in Guam with Newsmen. Online by Gerhard Peters, and John T. Woolley, the American Presidency Project. Retrieved from http://www.presidency.ucsb.edu/ws/?pid=2140

Nixon, R. (1992). Seize the Moment: America's Challenge in a One-Superpower World. New York, NY: Simon \& Schuster.

Pahlavi, M. R. (1966). White Revolution. Tehran, Bina.

Presidential Research \& Documentation Center. (2003). Documents from the Fourth Principle of Truman in Iran (1946-1967). With attempts by Teymour Bashir Gonbadi, Tehran: Ministry of Culture and Islamic Guidance.

Rorty, R. (1999). Achieving Our Country: Leftist Thought in Twentieth-century America. Harvard University Press.

Sadeq, Z. K. (2008). An Introduction to Islamic Revolution. Tehran, Rozaneh.

Saikal, A. (1980). The Rise and fall of the Shah: Iran from Autocracy to Religious Rule. Princeton University Press.

Sjöstedt, R. (2007). The Discursive Origins of a Doctrine: Norms, Identity, and Securitization under Harry S. Truman and George W. Bush. Foreign Policy Analysis, 3(3), 233-254. http://dx.doi.org/10.1111/j.1743-8594. 2007.00049.x

Torabi, Y. (2000). Relations of Iran and America. Tehran, Orouj institution of publication.

Worley, R. D. (2001). A Comparison of Cold War National Security Strategies. Washington, the Johsn Hopkins University.

\section{Notes}

Note 1. Domino Theory says that the international events, especially in one geographical region, are linked to one another like a chain. Accordingly, victory or defeat in one part results in victory or defeat in other parts. Designers of America's foreign policy justified Vietnam War like this too, saying that in case of a defeat to the 
northern Communist in the southern frontline, other regions of India, China, and neighboring states will fall under the supportive and political influence of USSR and Maoist China.

Note 2. One can call Melvin Laird, the defense minister of Nixon's government as the main designer of Vietnamization policy. He was a serious critic of the former governments' policy and also the policies of Robert McNamara, the previous defense minister. By posing this idea, he tried to reduce the unnecessary costs of his own ministry and consequently the sovereign government. For more information visit: http://www.defense.gov/ specials/secdef_histories/bios/laird.htm

\section{Copyrights}

Copyright for this article is retained by the author(s), with first publication rights granted to the journal.

This is an open-access article distributed under the terms and conditions of the Creative Commons Attribution license (http://creativecommons.org/licenses/by/3.0/). 